\title{
Analysis of the relationship between landslides and precipitation events in Chiriquí Province, Panama
}

\author{
Análisis de la relación entre deslizamientos y eventos de \\ precipitación en la provincia de Chiriquí, Panamá
}

\author{
David Heinz ${ }^{1 *}$, Casilda Saavedra ${ }^{2}$ \\ ${ }^{1}$ Wilkes University, ${ }^{2}$ Universidad Tecnológica de Panamá
}

\begin{abstract}
Anthropogenic activity has long been labeled as the leading cause of soil destabilization. However, natural factors including soil erosion and excess rainfall have also been some of the main causes of landslides. Panama is a country with a tropical climate and has a variety of soils that are susceptible to weakening by rainfall. Some contain a considerable amount of clay (Acrisols, Nitisols) while others do not (Andosols). Either kinds of soil are structurally weakened by large amounts of rain. The landslides produced by the destabilization of these soils have caused much damage in Panama. Chiriqui is a province that has seen an increase in landslides. This study, using historical meteorological and disaster data from 1985 until 2010, was focused on determining the relationship between the amount of average rainfall and the frequency of landslides in Chiriqui. The study found that Bugaba experienced the highest number of landslides during the study period and received considerable rainfall.
\end{abstract}

Keywords Landslides, rain, soil, Chiriqui.

Resumen La actividad antropogénica ha sido etiquetada durante mucho tiempo como la principal causa de desestabilización del suelo. Sin embargo, los factores naturales que incluyen la erosión del suelo y el exceso de lluvias también han sido algunas de las principales causas de deslizamientos de tierra. Panamá es un país con un clima tropical y tiene una variedad de suelos que son susceptibles a debilitarse por la lluvia. Algunos contienen una cantidad considerable de arcilla (Acrisols, Nitisols), mientras que otros no (Andosols). Ambos tipos de suelo son debilitados estructuralmente por grandes cantidades de lluvia. Los derrumbes producidos por la desestabilización de estos suelos han causado mucho daño en Panamá. Chiriquí es una provincia que ha visto un aumento en los deslizamientos de tierra. Este estudio, utilizando datos históricos meteorológicos y de desastres desde 1985 hasta 2010, se centró en determinar la relación entre la cantidad de precipitación promedio y la frecuencia de deslizamientos de tierra en Chiriquí. El estudio encontró que Bugaba experimentó el mayor número de deslizamientos de tierra durante el período de estudio y recibió lluvias considerables.

Palabras clave Deslizamientos, lluvia, suelos, Chiriquí.

*Corresponding author: david.heinz@wilkes.edu

\section{Introduction}

Landslides have been the focus of many studies in recent years due to their disruptive and destructive effects on human life and property. Expansion of urban centers through construction of roads and buildings has had a destabilizing effect on natural soil slopes. Though this effect has been increasing in recent time, there are other factors that cause destabilization in soils that are produced by the environment. Soil properties like clay content and permeability have a considerable effect on a soils ability to retain its structural strength under substantial loads or rainfall [1] [2]. It is common knowledge that rain affects the stability of soil in terms of loadbearing capacity due to the fact that as rain infiltrates into the soil, the soil moisture increases, which reduces the cohesion and shear strength of the soil [3][4].

The established relationship between rain and soil stability has led researchers, such as [5][6][7], to be more and more concerned with how much rain in given conditions will trigger or influence a landslide or other mass movements. Recently, statistical analysis of historical rain data in conjunction with historical landslide occurrences has enabled researchers to begin the process of creating modelling or prediction tools to characterize rain events as potential landslide-triggering events 
[7][8][9]. Several studies deal with the use of rainfall thresholds as a method to sort out any landslides that were not caused by rainfall to isolate the rainfall amounts that caused landslides in the past [7][8][10]. These tools would then allow governments to use weather forecasts to predict the possibility of landslides and mobilize the necessary resources to reduce the amount of damage caused by the event. Although these methods of prediction do not necessarily give specific locations where the landslides would occur, they do provide warning of precipitation events that could cause failure in any unstable slopes. The purpose of this study is to analyze damage caused by landlsides and the magnitude of the cumulative rainfall preceding the landslide. This would then identify areas that are more prone to landslides than others based on historical data.

Panama is a country that experiences landslides frequently. Panama has a tropical climate that experiences only dry and rainy seasons that are characterized by little rain and large, intense rain events respectively [11]. The combination of the tropical climate and the increase in construction throughout urbanizing areas has resulted in larger numbers of landslides and greater subsequent impacts.

Panama's soil types also have considerable effects on landslide occurrences due to most of the soil types having considerable clay contents. Soils like Andosols and Nitisols are common (figure 1), but there is considerable variation in soil type in boundary areas where geology changes.

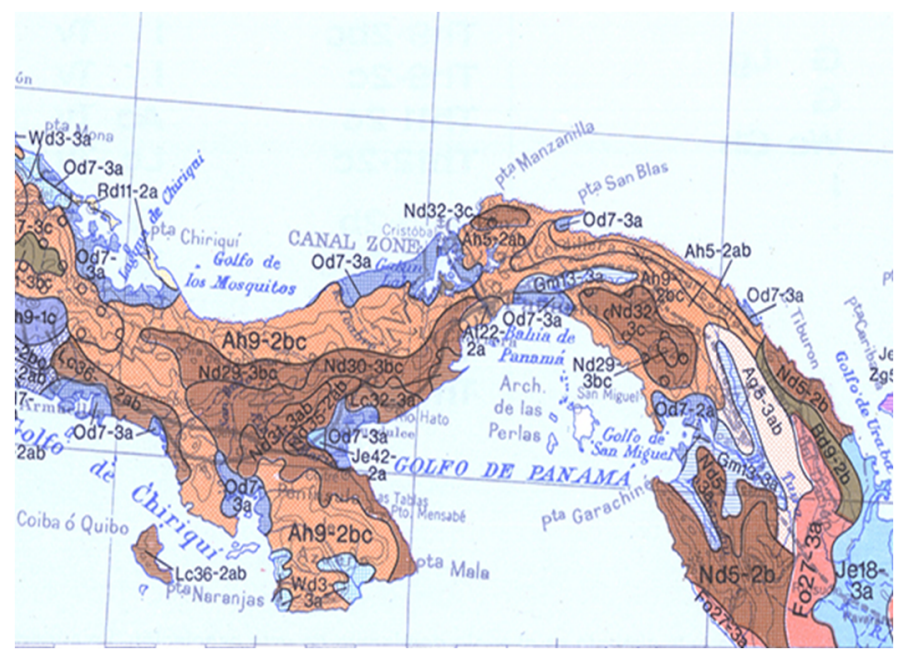

Figure 1. General soil map of Panama. Legend. Ah: Humic Andosols, Nd: dystric Nitisols, Od: dystric Histosols. Source: Food and Agriculture Organization (FAO) and United Nations Educational, Scientific, and Cultural Organization (UNESCO) [12].

The purpose of this study is to determine what districts in the province of Chiriquí is most susceptible to landslides and what the rainfall conditions are in those districts.

\section{Methodology \\ 2.1 Study Area}

The province of Chiriquí is on the western side of Panama and shares a border with Costa Rica. It is $6,491 \mathrm{~km}^{2}(2506.2$ $\left.m i^{2}\right)$ in area and constitutes the highest portion of the western highlands with a maximum elevation of $3.48 \mathrm{~km}(2.16 \mathrm{mi}$.) above sea level. The province is split up into 14 districts: Alanje, Barú, Boquerón, Boquete, Bugaba, David, Dolega, Gualaca, Remedios, Renacimiento, San Félix, San Lorenzo, Tierras Altas, and Tolé. It was chosen as the area of study due to the abundance of meterological stations and thereby meteorological data for that region. Landslide occurrences are becoming more common in this province, as there have been 22 significant landslide events between september and october, from 1986 to 1998.

The soil type of most of the region has played a part in this increase. Some of the soil types present in Chiriquí are a direct result of the weathering of underlying volcanic geology from Volcano Baru. The best example of this is represented by the ANum symbol in figure 2, which stands for Andosol. This type of soil is relatively young, has mineralogical similarities with its parent material, and low clay content.

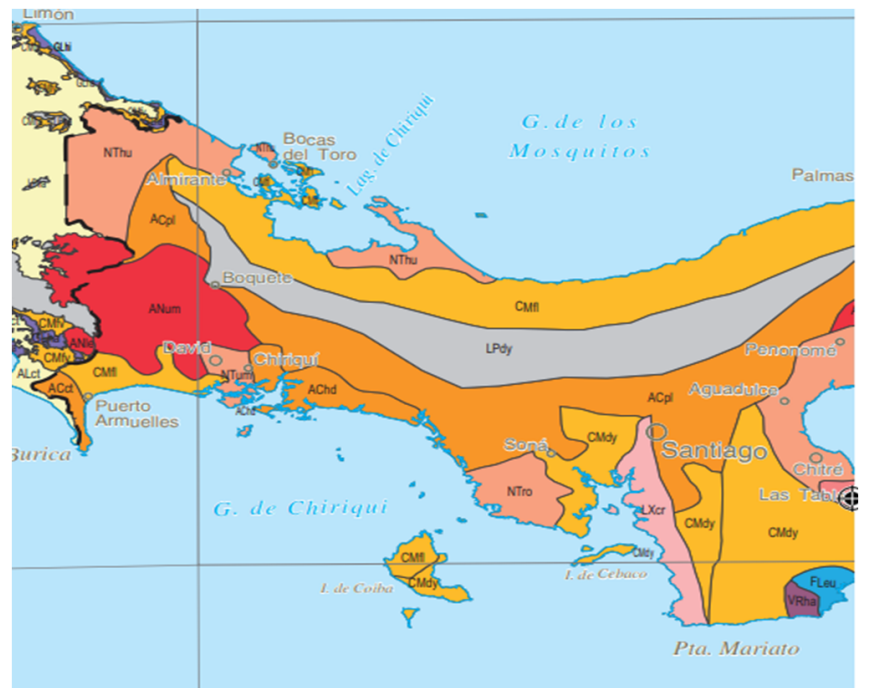

Figure 2. Soil map of Western Panama. (Legend:LPdy: Dystric Leptosols, CMfl: Ferralic Cambisols, ACct: Cutanic Acrisols, AChd: Haplic Acrisols, ACpl: Plinthic Acrisols, NTum: Umbric Nitisols, ANum: umbric Andosols) Source: Atlas de suelos de America Latina y el Caribe. (2014) [13].

The majority of Chiriquí is dominated by varieties of Acrisols (figure 2), which are often susceptible to erosion and dominated by stable, low-activity clays. There are also other soils in Chiriqui, like Andosols and Leptosols, which have low clay content, but are still influenced by rain to produce landslides once the soil is saturated enough to decrease surface friction (Seed, et al., 2008). Overall, rain is a major factor in 
both the formation of the soils present in Chiriquí as well as on the soils structural stability.

\subsection{Data collection}

Rain data was collected from the online meterological database operated by Empresa de Transmisión Eléctrica, S.A.(ETESA), which is the governmental agency responsible for the development and maintenance of the power lines in Panama. The data collected were daily measurements of precipitation taken from 23 stations across the entirety of Chiriquí. The time frame of the data was from May through December and reaching from 1986 to 2010. The purpose for choosing May through december was to analyze the average amount of rain each district received over the course of the rainy season to establish average precipitation conditions in Chiriquí. The measurements from these stations were used for statistical analysis of the precipitation on each day within the study period (june-december 1986-2010). The data for the landslides were downloaded from a database called DesInventar, which is operated and supported by Sistema Nacional de Proteccion Civil (SINAPROC) and United Nations International System for Disaster Reduction (UNISDR), among others. The database contains records of disaster events which contain information on what elements were affected (i.e. number of people affected, number of deaths, number of homes affected) and the event that was responsible, like landslides. This data was compared to analyze for trends.

\subsection{Statistical analysis}

The daily rainfall averages were used to produce yearly average rain amounts received by each district. The data was graphed in a scatter plot and then compared to the landslide data generated by the DesInventar database. Many other studies use more complicated statistical and modelling methods to characterize rain events using much more specific parameters [3][6][7][8]. Comparison of the overall amount of precipitation received in each district with the landslides that occurred within the study period there provided insight into which districts in Chiriquí are more at risk to landslides.

\section{Results}

Boquete and Bugaba districts were found to have experienced the most landslides in Chiriquí during the study period. This can be seen in figure 3. Bugaba was by far the most prone to landslides with a total of 15 landslides occurring within the study period. Boquete followed in landslide frequency with 8 landslides occurring within the study period. Tole, Baru, and David experienced equal numbers of landslides, but only fractions of the number of landslides that occurred in Boquete and Bugaba.

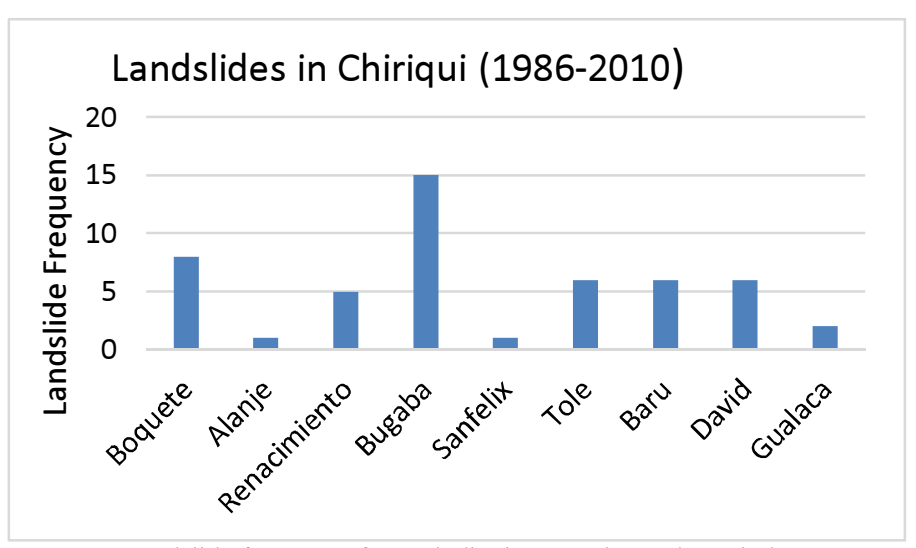

Figure 3. Landslide frequency for each district over the study period.

The rainfall data collected and averaged is displayed in figure 4 and gives further insight into the average precipitation conditions for each of the districts in question. Overall, San Felix seems to receive the greatest daily rainfall depths, but experienced the least landslides during the study period. Boquete and Bugaba received similar rainfall depths to districts that did not experience nearly as many landslides.

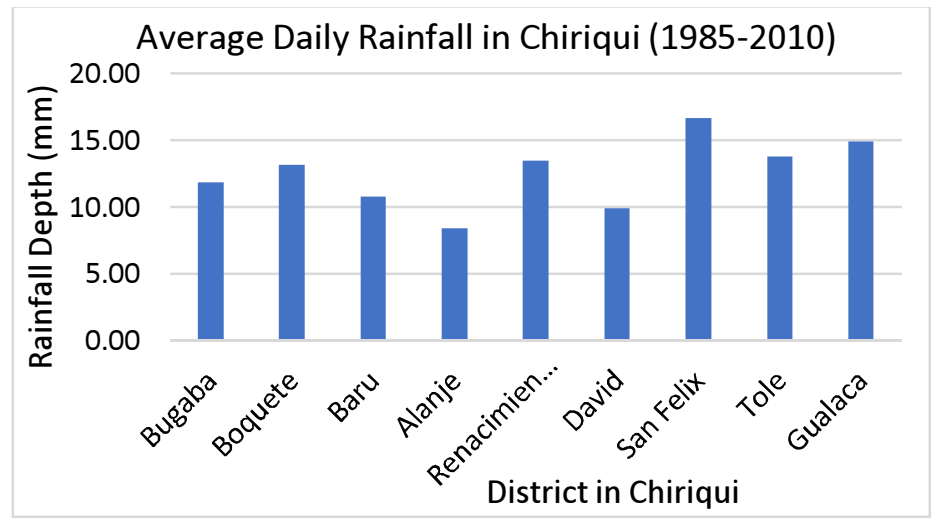

Figure 4. Average Daily Rainfall depths over the study period for each district in Chiriquí affected by landslides in the study period.

\section{Discussion}

The data presented in figures 4 and 5 seem to indicate that Boquete and Bugaba are the most prone to landslides in Chiriquí. The landslides that occurred in Boquete and Bugaba were possibly caused by lower average rainfall depths than other districts with fewer landslides. This is most likely due to the fact that Bugaba and Boquete have young, reactive soil that is more unstable than the more stable soil in areas like Tole and San Felix (see figure 2). Tole, Baru, and David are the next 
most susceptible to landslides and less if not more rainfall on average.

\section{Conclusions}

The study indicates that Bugaba was the most susceptible to landslides based on historical data, and the conditions that the landslides occurred in were a combination of unstable soil and considerable rainfall. The rest of the districts were influenced by rainfall because their soils are more stable than Bugaba.

\section{ACKNOWLEDGEMENT}

I would also like to thank Dr. Grajales and Dr. Muñoz for helping determine the feasibility of this project and help with gaining access to the appropriate data. I would like to give a very special thank you to Dr. Casilda for the mentoring and supportive work she has done throughout the research period. Thanks, should also be given to Wilkes University, la Universidad Tecnológica de Panama, and the $100 \mathrm{k}$ Strong in the Americas program for making this opportunity possible.

\section{REFERENCES}

[1] Tofani, V., Bicocchi, G., Rossi, G., Segoni, S., D'ambrosio, M., Casagli, N., \& Catani, F. (2017). Soil characterization for shallow landslides modeling: A case study in the northern apennines (central italy). Landslides, 14(2), 755-770. doi:http://dx.doi.org.ezproxy.wilkes.edu/10.1007/s10346-0170809-8.

[2] Beyabanaki, S. A. R., Bagtzoglou, A. C., \& Anagnostou, E. N. (2016). Effects of groundwater table position, soil strength properties and rainfall on instability of earthquake-triggered landslides. Environmental Earth Sciences, 75(4), 1-13. doi:10.1007/s12665-016-5277-2.

[3] Ho, K. K., S., Chao, P. A., Lau, T. M., F., \& De Silva, S. (2013). Investigation of the 20 august 2005 fatal landslide at fu yung shan tsuen, hong kong. Landslides, 10(3), 285297.doi:http://dx.doi.org.ezproxy.wilkes.edu/10.1007/s10346012-0332-x.

[4] Galeandro, A., Doglioni, A., Simeone, V., \& Šimůnek, J. (2014). Analysis of infiltration processes into fractured and swelling soils as triggering factors of landslides. Environmental Earth Sciences, 71(6), 2911-2923. doi:10.1007/s12665-0132666-7.

[5] Iadanza, C., Trigila, A., \& Napolitano, F. (2016). Identification and characterization of rainfall events responsible for triggering of debris flows and shallow landslides. Journal of Hydrology, 541, 230-245. doi: 10.1016/j.jhydrol.2016.01.018.

[6] Borga, M., Stoffel, M., Marchi, L., Marra, F., \& Jakob, M. (2014). Hydrogeomorphic response to extreme rainfall in headwater systems: Flash floods and debris flows. Journal of Hydrology, 518, 194-205. doi:10.1016/j.jhydrol.2014.05.022.
[7] Zêzere, J. L., Vaz, T., Pereira, S., Oliveira, S. C., Marques, R., \& Garcia, R. A. C. (2015). Rainfall thresholds for landslide activity in portugal: A state of the art. Environmental Earth Sciences, 73(6), 2917-2936. doi:10.1007/s12665-014-3672-0.

[8] Piciullo, L., Gariano, S. L., Melillo, M., Brunetti, M. T., Peruccacci, S., Guzzetti, F., \& Calvello, M. (2017). Definition and performance of a threshold-based regional early warning model for rainfall-induced landslides. Landslides, 14(3), 9951008. doi:10.1007/s10346-016-0750-2.

[9] De Oliveira, N. S., Rotunno Filho, O. C., Marton, E., \& Silva, C. (2016). Correlation between rainfall and landslides in nova friburgo, rio de janeiro--brazil: A case study. Environmental Earth Sciences, 75(20), 1-12. doi:http://dx.doi.org.ezproxy.wilkes.edu/10.1007/s12665-0166171-7.

[10] Sengupta, A., Gupta, S., \& Anbarasu, K. (2010). Rainfall thresholds for the initiation of landslide at lanta khola in north sikkim, india. Natural Hazards, 52(1), 31-42. doi:10.1007/s11069-009-9352-9.

[11] Hidromet.com.pa. (2018). Panama Hydrologic Regime Hidrometeorología de ETESA. [online] Available at: http://www.hidromet.com.pa/regimen_hidrologico.php?idiom $\mathrm{a}=$ ing [Accessed 26 Jul. 2018].

[12] UNESCO. Food and Agriculture Organization (FAO) and United Nations Educational, Scientific, and Cultural Organization.

[13] Atlas de suelos de America Latina y el Caribe. (2014). Luxemburgo: Oficina de publicaciones de la Unión europea. 